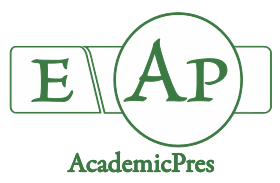

El-Baroty GS et al. (2020)

Notulae Botanicae Horti Agrobotanici Cluj-Napoca 48(2):666-680

DOI: $10.15835 /$ nbha48211670

Research Article

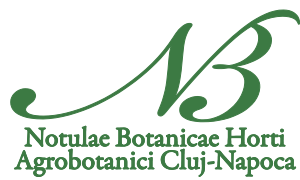

\title{
Egyptian Arthrospira phytosterols: production, identification, antioxidant and antiproliferative activities
}

\author{
Gamal S. El BAROTY' ${ }^{1 *}$, Hanaa H. Abd El BAKY2*, \\ Mahmoud A. SALEH ${ }^{1,3}$ \\ ${ }^{1}$ Cairo University, Faculty of Agriculture, Biochemistry Department, Cairo, Egypt; elbarotys@hotmail.com ( ${ }^{*}$ corresponding author) \\ ${ }^{2}$ National Research Center, Plant Biochemistry Department, Dokki, Giza, Egypt; abdelbakyhanaa@yahoo.com \\ ${ }^{3}$ Texas Southern University, Department of Chemistry, Houston, Texas, 77004, USA
}

\begin{abstract}
Cultivation of microalgae as a source of phytosterol and other lipid compounds has gained more attention for commercial applications in pharmaceutical, cosmetic and food function industries. In this research, native Spirulina maxima SM from Egypt was grown in individual cultures containing various concentrations of nitrogen $(\mathrm{N})$, phosphorus $(\mathrm{P})$ and sulfur $(\mathrm{S})$ elements in order to elucidate the effect of its elements on lipid and phytosterols production and to evaluate its antioxidant and antiproliferative activities. The results revealed that the SM was able to grow in different concentrations of testing elements $S$ (from 0.3 to $2.4 \mathrm{mM}$ ), P (from 0.3 to $2.4 \mathrm{mM}$ ) and $\mathrm{N}(0.3$ to $3.2 \mathrm{mM}$ ) with significant differences. A high potential for production of MS biomass, total lipid and phytosterol contents were obtained in individual cultures containing $0.6 \mathrm{mM} \mathrm{N}, 0.6 \mathrm{mM}$ P and $0.80 \mathrm{mM}$, respectively. Therefore, these concentrations (combination of $\mathrm{S}+\mathrm{P}+\mathrm{N}$ element) were selected for cultivation of SM at large scale in a column photobioreactor (PBR $300 \mathrm{~L}$ ) to induce sufficient SM biomass so that, we can obtain an adequate amount of total lipid and phytosterol contents. Phytosterols (PS) of native SM grown in the 300 L PBR were partially purified from unsaponified extracts of SM total lipid followed by its purification by crystallization process. The identification and quantification of PS profile were performed by GC-FID analysis. The results revealed high levels of campsterol, $D^{7}$-Avena sterol, $\beta$-sitosterol, stigmasterol and other compounds. These PS compounds showed marked in vitro superoxide, $\mathrm{DPPH}$ and $\mathrm{OH}$ radical scavenging activity, which was comparable with the results obtained with standard antioxidants BHA or $\alpha$-tocopherol. Moreover, SM phytosterols exhibited anti-proliferative activity against three human cancer cell lines (MCF-7, Hep-G2 and HCT-116) with IC $_{50}$ values less than $11.62 \mu \mathrm{g} / \mathrm{mL}$ as assessed by in vitro MTT colorimetric method. Thus, SM phytosterol may be considered as a potential natural source of promising ingredient in the future for a range of health applications for human, cosmetic industries and in functional food.
\end{abstract}

Keywords: antioxidant; antiproliferative; microalgae Spirulina maxima; phosphorus; phytosterols; sulfur and nitrogen limitation 


\section{Introduction}

The phytosterol compositions of the microalgae are structurally related to cholesterol, but differ from cholesterol in the structure of the side chain. Currently, phytosterols (C28 and C29 sterols) are playing an important role in nutraceutic, pharmaceutical and functional foods industries. Also, they are precursors of vitamin D2 and other bio-active molecules (Andrade et al., 2018). Phytosterols (PSs) showed some therapeutic applications to treat hypercholesterolemia and have lowering effect on total and low-density-lipoprotein (LDL)-cholesterol in human and may have value in treating complications of diabetes and hypertension (Luo et al., 2015; Abdul et al., 2016). In addition, PSs may possess anti-inflammatory, anti-atherogenicity, anticancer and anti-oxidative activities and may provide protective effect against nervous system disorders such as autoimmune encephalomyelitis or Alzheimer's disease (Ahmed et al., 2015; Koh et al., 2018). The world market for PSs was estimated at 1000 tons per year, and the market is expanding, due to increase its application in cosmetic and pharmaceutical industries. In 2012, the phytosterols markets in European were about 196 million US\$ and global market was about 300 million US\$ and it is expected to increase by 7-9\% annually (Borowitzka, 2013). Nowadays, the consumers are actively seeking products containing health-promoting ingredients such as phytosterols, phycocynin and polyunsaturated fatty acids, to improve the state of health or well-being and reduce the risk of disease (Abd El Baky et al., 2014, 2016). Thus, research is focusing on identifying new natural sources of phytosterols and microalgae which have been demonstrated as a suitable alternative source of these functional compounds (Borowitzka, 2013; Andrade, 2018). However, some phytosterols (ß-sitosterol, campesterol and stigmasterol) are subject to the FDA health claim and it could be used in the food market, including breakfast cereals, cereal bars and milk (Luo et al., 2015; Srigley and Haile, 2015).

Microalgae are the main source of phytosterols for zooplankton and fish and these compounds become increased in all arthropods which food quality greatly depends on the sterol composition of algal species in the zooplankton diet (Martin-Creuzburg and Von Elert, 2004). However, the biochemical composition of microalgae under normal conditions is characterized by a wide percentage of proteins (up to 60\%), carbohydrates (up to 40\%), lipids (up to 15\%) and carotenoids (Abd El Baky and El Baroty, 2012, 2013). The biochemical flexibility (capacity of protein, lipids and pigments (include: chlorophyll, carotenoids and phycobilliproteins) accumulation is depending on the microalgae species and on the environmental and nutritional conditions (Abd El Baky et al., 2009; El Baroty et al., 2011). The main environmental factors influencing biosynthesis pathways of bio-molecules are light intensity, $\mathrm{pH}$ and salinity, while the nutritional factors have included the availability and source of nitrogen, carbon and iron (Abd El Baky and El Baroty, 2012, 2016; Shanthi et al., 2018). However, microalgae have many advantages to be utilized for production of biomolecules that possess high growth rate, the possibility of culturing them in non-arable lands and the use of less- and lower-quality water. In algae, research has focused on the diverse sterol composition of different species but there are few studies that deal with the influence of culture conditions on the sterol content or composition of microalgae. Gordillo et al. (1998) suggests that the phytosterol content of algae changes under different environmental conditions, such as nutrient sources or light intensity. As yet, however, simultaneous effects of nutrient availability on quantity and quality of sterol accumulation in $S$. maxima grown at large scale in photobioreactor have not been considered. Therefore, in this investigation, we examined the influence of adding various concentrations of phosphorus, sulfur and nitrogen elements on S. maxima growth medium on total lipid contents and phytosterol yield. The best concentration produces TL and PS was selected for cultivation of SM at large scale in photobioreactor (combination of $\mathrm{S}+\mathrm{P}+\mathrm{N}$ element, PBR $300 \mathrm{~L}$ ) to induce and obtain highest values of total lipid and phytosterol PS contents. The PS composition, its antioxidant and antiproliferative activities were determined. 


\section{Materials and Methods}

Algal source

Blue green algae, native Spirulina (Arthropira) maximas (SM) use in this study, were isolated from Egypt, and maintenance in our current culture collection, algae unit in Plant Biochemistry Department (it cited in EMCCN), National Research Centre, Giza, Egypt. The details of the SM strain and the protocol for the maintenance of pure culture in Zarrouk's medium (Zarrouk, 1966) as described previously (Abd El Baky et al., 2006).

\section{Reagents}

All reagents and chemicals used in the experiments were of analytical grade and purchased from SigmaAldrich Chemical Company (St. Louis, MO, USA) and were stored according to the vendor's instructions.

\section{Cultivation of algae}

Effect of phosphorus concentration on lipid accumulation and Spirulina platensis biomass

The SM was cultivated in Zarrouk's medium (Zarrouk, 1966). Phosphorus (P) was supplied as $\mathrm{KH}_{2} \mathrm{PO}_{4}$ with the serious concentrations of viz., $0.3,0.6,1.2 \mathrm{mM}$ and $2.4 \mathrm{mM}$ phosphorus into a different flask $(2 \mathrm{~L})$ containing 1.7 L Zarrouk medium. Aeration was accomplished using air pumps to achieve an air flow rate of $20 \mathrm{~L} / \mathrm{h}$. The cultures were gassed with $0.03 \%$ volume $\mathrm{CO}_{2}$ in an air and temperature was maintained at $25^{\circ} \mathrm{C}$ $\pm 3{ }^{\circ} \mathrm{C}$. The $\mathrm{pH}$ of all media was adjusted to 8.5 . The cultures were illuminated with continuous 10 cool white fluorescent lamps (Philips $40 \mathrm{~W}$ ) provided an illumination of 2500 lux. In all cultivated flasks, conductivity, salinity, $\mathrm{pH}$ and temperature were daily measured within 10 days of growth by Hanna (HI 09812-5) conductivity. The purity of cultures was periodically checked by microscopic observation following taxonomy guidelines. All solutions and glassware were autoclaved at $121^{\circ} \mathrm{C}$ for $15 \mathrm{~min}$ prior to use.

\section{Effect of sulfur concentration on lipid accumulation and SM biomass}

The sulfur concentrations were adjusted to $0.20,0.40,0.80,1.60$ and $3.20 \mathrm{mM}$ by supplementation with as potassium sulfate $\mathrm{K}_{2} \mathrm{SO}_{4}$ into a different flask $(2 \mathrm{~L})$ containing $1.7 \mathrm{~L}$ Zarrouk medium. All flasks were incubated at the same conditions as described previously.

\section{Effect of nitrogen concentration on lipid accumulation and SM biomass}

Effect of nitrogen, four concentrations of $\mathrm{KNO}_{3}(0.3,0.6,1.2$, and $3.2 \mathrm{mM})$ were maintained in flask (2 L) containing 1.7 L Zarrouk medium. All flasks were incubated at the same conditions as described previously.

\section{Cultivation of S. maxima at large scale}

The SM was cultured in Zarrouk's medium containing a combination of nitrogen, sulfur and phosphorus limitation $(0.6 \mathrm{mM} \mathrm{N}+0.6 \mathrm{mM} \mathrm{P}+0.80 \mathrm{mM} \mathrm{S})$ in $300 \mathrm{~L}$ column photoreactor.

The cultivation of SM culture in photobioreactor was achieved at the same conditions as described previously.

\section{Growth measurements and harvesting}

The growth rate of SM was monitoring every three days through the entire cultivation period by determining the cell dry weight ( $\mathrm{dw}$, gravimetrically) and by optical density at OD $560 \mathrm{~nm}$. A good linear relationship between the biomass DW concentration and the OD $560 \mathrm{~nm}$ was recorded. The cells were harvested at the stationary phase ( 10 days), by centrifugation at $10,000 \mathrm{xg}\left(4^{\circ} \mathrm{C}\right)$ for $15 \mathrm{~min}$ and the cell masses were stored at $-20^{\circ} \mathrm{C}$ until analysis. All analytical determinations were performed in triplicate and the mean values were recorded. 


\section{Determination of lipid content}

\section{Lipid extraction}

The harvested cells $(10 \mathrm{~g})$ were washed several times with deionized water, lyophilized for lipid extraction (Bligh and Dyer, 1959). The total lipids were extracted with chloroform-methanol $(2: 1, \mathrm{v} / \mathrm{v})$, and then separated into chloroform (bottom layer) and aqueous methanol layers by the addition of methanol and water to give a final solvent ratio of about chloroform: methanol: water of 1:1:1. The organic (chloroform) layer was cleaned using a saturated $\mathrm{NaCl}$ water solution and the chloroform phase was recovered using a separator funnel. The chloroform phase was dried with sodium sulfate overnight, and evaporated to dryness under reducing pressure. Purified lipids were measured gravimetrically and stored at $-20^{\circ} \mathrm{C}$ under nitrogen gases to prevent of lipid auto-oxidation or used directly for subsequent analysis.

\section{Extraction of phytosterols from MS oil}

The total lipids were saponified by refluxing with $5 \%(\mathrm{w} / \mathrm{v}) \mathrm{KOH}$ methanol/water $(4: 1, \mathrm{v} / \mathrm{v})$ solution for $3 \mathrm{hrs}$. After addition of 2 volumes of distilled water, unsaponified in the combined solution was then extracted four times with $25 \mathrm{~mL}$ of di ethyl ether. The ether phases were then combined, dried with sodium sulfate overnight, filtered and evaporated to dryness. The residue weighted after drying to constant weight.

\section{Separation of Spirulina maxima phytosterols}

Total sterols from unsaponified material were semi purified by crystallization process as described by Chuanphongpanich et al. (2006).

\section{Crystallization and filtration}

A portion of the unsaponified material (USM, $0.2 \mathrm{~g}$ ) was dissolved in the minimal volume of hot ethylene dichloride and then subsequent freezing to precipitate sterol fractions. The resulting crystals of steroid fraction were collected by vacuum filtration. When all the crystals have been transferred, they were washed with a small amount of the cold ethylene dichloride and the solvent was completely removed in a vacuum. The sterol yield was $0.16 \mathrm{~g}$ ( $80 \%$ of the USM).

\section{$\underline{\text { Recrystallization }}$}

The crystals $(0.1 \mathrm{~g})$ were dissolved in hexane $(20 \mathrm{ml})$, then a volume of water $(10 \mathrm{ml})$ was added to react with the sterols (one water molecule per two sterol molecules) to form a semi hydrate slurry, which is insoluble in hexane, and will form a precipitate. The resulting slurry, of which seemed to be phytosterols fraction were obtained and it is probable that there are several sterols present in this SM. The fraction was filtered to separate the crystals from the solution. The crystals of steroids fraction were filtered and washed with cold hexane and the solvent was completely removed under $\mathrm{N}$ gases. The sterols yellow crystals yield was $0.072 \mathrm{~g}$.

\section{Identification of Spirulina maxima phytosterols}

The steroid of SM was analyzed with an HP 5890 gas chromatograph equipped with FID detector and DB-5 capillary column (30 m, $0.25 \mathrm{~mm}$ (5\%-phenyl) - 95\%-methyl-polysiloxane, 0.25 um film thickness, 28 $0^{\circ} \mathrm{C}$ temperature injector and $300^{\circ} \mathrm{C}$ temperature transfer line. The oven temperature was programmed as follows: initial temperature $100^{\circ} \mathrm{C}$ for $2 \mathrm{~min}$, increase $10^{\circ} \mathrm{C} / \mathrm{min}$ up to $300^{\circ} \mathrm{C}$ and then hold (isothermal) at $300^{\circ} \mathrm{C}$ for $20 \mathrm{~min}$. Helium was used as the carrier gas at a constant flow rate of $1.0 \mathrm{~mL} \mathrm{~min}{ }^{-1}$. The identification of sterols was based on the comparison of their retention times relative to authentic sterols cholesterol ( $5 \mathrm{a}-$

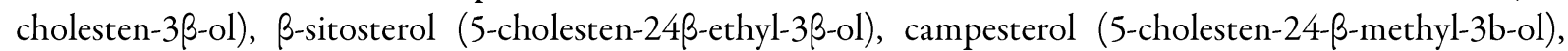
ergosterol (24 $\beta$-methyl-cholesta-5,7,22-trien-3ß-ol) and stigmasterol (5,22-cholestadien-24- ethyl-3 $\beta$-ol) represented the main phytosterols) standards (Aldrich-Sigma, purity $>98 \%$ by GC). The relative percentage (\%) of each component was evaluated by comparing its average peak area to the total areas. Moreover, the identification of SM phytosterols was confirmed based on steroids the elution order in the literature data 
steroids as following order: cholesterol $<$ brassicasterol $<$ campesterol $<$ campestanol $<$ stigmasterol $<$ sitosterol $<$ sitostanol $<\Delta 5$-avenasterol (Winkler-Moser, 2018).

\section{Antioxidant activity}

\section{DPPH radical scavenging assay}

The SM phytosterolss was assayed with DPPH (1,1-diphenyl-2-picrylhydrazyl) radical, previously dissolved in methanol. Methanolic solution of DPPH radicals was freshly prepared at a concentration of $0.02 \%$, this solution was stable for more than $2 \mathrm{~h}$. For assay, in test tube $40 \mu \mathrm{l}$ was added to $1 \mathrm{ml}$ conained series concentration of 1.0 to $32.0 \mathrm{ug} / \mathrm{ml}$ of MS-PS and was vortexed for $20 \mathrm{~s}$ and incubated in the dark at ambient temperature $30^{\circ} \mathrm{C} \pm 2{ }^{\circ} \mathrm{C}$. Against a blank of pure methanol without $\mathrm{DPPH}$, the decrease in absorption at 515 $\mathrm{nm}$ was measured in 1-cm quartz cells after $30 \mathrm{~min}$ of mixing using $\mathrm{UV} /$ visible spectrophotometer (Thermo, USA). The inhibition percent was calculated from the following equation:

Inhibition $\left.\%=\left(\mathrm{A}_{0}-\mathrm{A} 1\right) / \mathrm{A}_{0}\right) \times 100$ (Equation $\left.\mathrm{I}\right)$

Where: $\mathrm{A}_{0}$ is the absorbance of control and $\mathrm{A} 1$ absorbance of the test. The obtained dose response curves were used to calculate the $\mathrm{IC}_{50}$ value, which is the effective concentration at which the antioxidant activity is $50 \%$.

\section{$\underline{\text { ABTS radical scavenging assay }}$}

ABTS radical scavenging activity was determined according to the Re et al. (1999) method. The ABTS solution was prepared and stored in the dark at room temperature for $16 \mathrm{~h}$. The working ABTS solution was prepared by adding $1 \mathrm{~mL}$ of the solution was diluted with $40 \mathrm{~mL}$ deionized to give an absorbance equal to 0.70 \pm 0.02 at $734 \mathrm{~nm}$. To $100 \mu \mathrm{L}$ ABTS solution, $400 \mu \mathrm{L}$ test samples SM-PS at serial concentrations (2 to 64 $\mu \mathrm{l} / \mathrm{ml}$ ) were added.

After $10 \mathrm{~min}$, the absorbance of the solution was read at $734 \mathrm{~nm}$. The scavenging capability of ABTS was calculated using the following equation: (Equation I).

\section{Hydroxyl radicals HO radical-scavenging activity}

Hydroxyl radicals were generated by a Fenton reaction ( $\mathrm{Fe}^{+}$- ascorbate-EDTA- $\mathrm{H}_{2} \mathrm{O}_{2}$ system), and the scavenging capacity towards $\mathrm{HO}$ radicals was determined spectrophotometrically at $532 \mathrm{~nm}$ by using deoxyribose method (Halliwell et al., 1987). The negative control without any antioxidant or test sample (SMPS) was considered $100 \%$ deoxyribose oxidation. The $\%$ hydroxyl radical scavenging activity of test sample was determined accordingly in comparison with negative control. BHT and alpha-tecopherol was taken as the positive control. The inhibition \% was expressed, according to the following equation: $(\%)=\left[\mathrm{A}_{0}-(\mathrm{A} 1-\right.$ A2) $] / A_{0} \times 100$, where: $A_{0}$ is the absorbance of the control without a sample, $A 1$ is the absorbance in the presence of the sample and deoxyribose and $\mathrm{A} 2$ is the absorbance of the sample without deoxyribose.

\section{$\underline{\text { Superoxide radical scavenging assay }}$}

The superoxide $\mathrm{O}$ - radicals generated from the photo reduction of riboflavin was detected by Nitro blue tetrazolium (NBT) reagent (contained EDTA $(0.1 \mathrm{M}), 0.0015 \% \mathrm{NaCN}$, riboflavin $(0.12 \mathrm{mM}), \mathrm{NBT}(1.5$ $\mathrm{mM})$ ). In test tube, the NPT mixture and various concentrations of tested sample (SM-PS) and phosphate buffer $(67 \mathrm{mM}, \mathrm{pH} 7.8)$ were added in a total volume of $3 \mathrm{ml}$. The tubes were uniformly illuminated for 15 min and optical density was measured at $530 \mathrm{~nm}$ before and after the illumination (McCord and Fridovich, 1969). The percentage inhibition was calculated by using Equation (I). The BHT and alpha-tocopherol was used as a positive control. All experimental procedures were performed in triplicate and their mean values (standard deviation) were given. 


\section{Antiproliferative activity of SM phytosterols}

\section{Cell culture}

The antiproliferative effect of SM was investigated on three human cancer cell lines MCF-7 (breast adenocarcinoma cells), Hep-G2 (hepatocellular carcinoma cells) and HCT-116 (colon carcinoma cells) were provided by the Cambrex BioScience (Copenhagen, Denmark). Antiproliferative of the prepared steroid of SM and etoposide (positive control, $5-25 \mathrm{ug} / \mathrm{ml}$ ) samples on the cancer cells was determined using MTT (3(4, 5-Dimethylthiazol-2-yl)-2,5 diphenyltetrazolium bromide) in vitro method. The cancer cells were cultured in DMEM (Dulbeco's Modified Eagle's Medium) supplemented with $10 \%$ fetal bovine serum, Lglutamine $(2 \mathrm{mmol} / \mathrm{l})$, penicillin $\mathrm{G}$ sodium $(100 \mathrm{U} / \mathrm{ml})$, streptomycin sulfate (100 units $/ \mathrm{ml})$, amphotericin B $(250 \mathrm{ng} / \mathrm{ml})$ and maintained at $37^{\circ} \mathrm{C}$ with $5 \% \mathrm{CO}_{2}$ in a humidified atmosphere of $95 \%$ air. For sub-culturing, monolayer cells were harvested after trypsin/EDTA treatment at $37^{\circ} \mathrm{C}$. Cells were used when confluence had reached $75 \%$.

\section{Cytotoxic assay}

Cells $\left(0.5 \times 10^{5}\right.$ cells/ well $)$ were seeded in 96-wells microplates, and treated with $20 \mu \mathrm{l}$ of SM solution (DMSO, dimethyl dimethylsulphoxide) at concentrations ranging from $1.0-100 \mu \mathrm{l} / \mathrm{l}$; subsequently the cells were incubated for $48 \mathrm{~h}$ at $37^{\circ} \mathrm{C}$. After incubation, cell suspension was mixed with $2 \mu \mathrm{l}$ of MTT $(5 \mathrm{mg} / \mathrm{ml}$ of MTT in $0.9 \% \mathrm{NaCl}$ ) solution/ well and incubated for an additional $4 \mathrm{~h}$. MTT crystals were solubilized by adding $180 \mu \mathrm{l}$ of acidified isopropanol $(0.04 \mathrm{~N} \mathrm{HCl}$ in absolute isopropanol) / well and plate was shacked at room temperature. Viable cells were determined by the absorbance at $570 \mathrm{~nm}$ with a microplate reader (BioRad, Richmond, CA). Measurements were performed in three independed assays, using five replicates for each assay and the concentration required for a $50 \%$ percent inhibition of viability $\left(\mathrm{IC}_{50}\right)$ was determined.

\section{Statistical analysis}

All measurements were carried out on samples drawn in triplicate and the data presented are mean of three replicates $( \pm S D)$ standard deviations. Statistical analyses were performed using one-way analysis of variance ANOVA, and the significance of the difference between the means was determined by Duncan's multiple range procedure. A p-value $(\mathrm{P}<0.05)$ less than 0.05 were regarded significantly different.

\section{Results and Discussion}

Recently, several research initiatives have proven that Spirulina sp. microalgae biomass appear to be the one of the promising sources for the technological production of value-added phycocyanine and other fine chemicals (Colla $e t$ al., 2007). To enhance the feasibility of microalgae as a source of lipid rich in $\dot{\omega}-3$ and steroids, many reports have searched for microalgae species which not only have high biomass productivity, but also have high lipid content, when cultivated under define conditions, such as high iron concentration, nitrogen and phosphate limitation and salt stress (Abd El Baky et al., 2016, 2009).

\section{Effect of phosphorus $(P)$ concentrations on SM growth and total lipid content}

The impact of various phosphorus concentrations (P, 0.3, 0.6, $1.2 \mathrm{mM}$ and $2.4 \mathrm{mM}$ ) on the biomass (DW), total lipid productivity and total lipid contents of SM cells grown in Zarrouk's medium for 15 days are shown in Table 1 . The values of these parameters were significantly different $(P>0.5 \%)$ among all cultures, with various degrees. The maximum biomass concentration (DW) of $2.76 \pm 0.21 \mathrm{DW} \mathrm{g} \mathrm{L}^{-1}$ was obtained at 2.4 $\mathrm{mM}$ P, followed by $1.87 \pm 0.12 \mathrm{~g} \mathrm{~L}^{-1}$ at $1.2 \mathrm{mM} \mathrm{P}$. At low $\mathrm{P}(0.3 \mathrm{mM})$ concentration, the lower $\mathrm{DW}$ was obtained with a value of $0.754 \pm 0.08 \mathrm{DW} \mathrm{g} \mathrm{L^{-1 }}$. Trend of biomass yield in SM cells was almost linear with increasing P in growth medium. However, Celekli et al. (2009) observed that phosphate concentration more 
than $0.5 \mathrm{~g} / \mathrm{l}$ causes a decrease $(\mathrm{p}<0.01)$ in biomass production in $S$. platensis cultuers. Chiu et al. (2009) found that optimal growth potential of Chlorella sp. and $N$. oculata was recorded at $2 \mathrm{mM} P$ concentration. Whereas, in D. terticlecta culture the higher growth rates were obtained at $1.6 \mathrm{~m} \mathrm{MP}$ (Tang et al., 2010).

As shown in (Table 1), the total lipid content (19.13-39.22\%,w/ DW) in SP cells showed increasing trends with the decreased of $\mathrm{P}$ level in growth medium. The TL contents in culture cultivated at 2.4, 1.2, 0.6and $0.3-\mathrm{mM}$ phosphorus were found to be $19.13 \%, 27.98 \%$ and $39.22 \%, 35.14 \%$, respectively. Thus, highest accumulation of TL $(39.22 \%, w / w)$ and lipid yields $(0.659 \mathrm{~g} / \mathrm{L})$ were obtained at $0.6 \mathrm{mom}$, this could attribute to high microalgae growth and contribute to more biomass as nitrogen source. These data were in accordance with the results of (Tang et al., 2011) who reported that the accumulation of TL was enhanced as resulted to changing the phosphorus concentration to be $0.6 \mathrm{mM}$.

\section{Effect of sulfur concentration on SM growth and total lipids}

As shown in Table 2, the DW biomass of cultures supplemented with the $160 \mathrm{mg} \mathrm{L}^{-1}$ sulfur concentration (SCs, $3.09 \pm 0.32 \mathrm{~g} \mathrm{~mL}^{-1}$ ) was higher than that obtained in cultures supplemented with 20,40 and $80 \mathrm{mg} \mathrm{L}^{-1} \mathrm{SCs}\left(1.75 \pm 0.14,2.32 \pm 0.17\right.$ and $\left.2.67 \pm 0.23 \mathrm{~g} \mathrm{~L}^{-1}\right)$. Total lipid contents (TL) and lipid yield (LY) (in parentheses) of SM cells showed an increased trend with increasing sulfur concentration in a nutrient medium (Table 2). The maximum TL was $34.29 \%(0.916 \mathrm{~g} / \mathrm{L})$ was obtained at $80 \mathrm{mg} \mathrm{L}^{-1}$ sulfur, followed by $30.74 \%(0.713 \mathrm{~g} / \mathrm{L})$ at $40 \mathrm{mg} \mathrm{L}^{-1}$ sulfur $(0.472 \mathrm{~g} / \mathrm{L})$ at $20 \mathrm{mg} \mathrm{L}^{-1}$ sulfur , then $18.43 \%(0.569 \mathrm{~g} / \mathrm{L})$ at $160 \mathrm{mg}$ $\mathrm{L}^{-1}$ sulfur. In general, the levels of TL and lipid yield (LY) in algal culture supplemented with $S$ concentrations range between $20-160 \mathrm{mg} \mathrm{L}^{-1}$ significantly $(\mathrm{P}<0.05)$ increased with sulfur limitation. Liu et al. (2008) reported that a significant increase in lipid content $(20-50 \%, \mathrm{dw})$ occurred in many microalgae after being subjected to phosphate and sulfur depletion, which the metabolic pathways could be modified toward lipid biosynthesis.

Table 1. Effect of phosphorus concentrations on lipid content and biomass of Spirulina maxima

\begin{tabular}{|c|c|c|c|c|}
\hline $\begin{array}{c}\text { Phosphorus conc. } \\
(\mathrm{mM})\end{array}$ & \multicolumn{2}{|c|}{$\begin{array}{c}\text { Biomass } \\
(\text { dry weight } \mathrm{g} / \mathrm{L})\end{array}$} & $\begin{array}{c}\text { Lipid content } \\
(\%)\end{array}$ & $\begin{array}{c}\text { lipids yield } \\
(\mathrm{g} / \mathrm{L})\end{array}$ \\
\hline 0.3 & 0.75 & $\pm 0.08^{\mathrm{a}}$ & $35.14 \pm 1.41^{\mathrm{c}}$ & $0.265 \pm 0.057 \mathrm{~b}$ \\
\hline 0.6 & 1.68 & $\pm 0.11 \mathrm{~b}$ & $39.22 \pm 1.98^{\mathrm{d}}$ & $0.659 \pm 0.076^{\mathrm{d}}$ \\
\hline 1.2 & 1.87 & $\pm 0.12 \mathrm{c}$ & $27.98 \pm 0.697^{\mathrm{b}}$ & $0.523 \pm 0.087 \mathrm{a}$ \\
\hline 2.4 & 2.76 & $\pm 0.21 \mathrm{~d}$ & $19.13 \pm 0.576^{\mathrm{a}}$ & $0.528 \pm 0.077 \mathrm{c}$ \\
\hline
\end{tabular}

Each value represents the mean of three replicates and based on dry weight

All values are significant at $(\mathrm{P}<0.5)$.

Table 2. Effect of sulfur concentrations on lipid content and biomass of Spirulina maxima

\begin{tabular}{|c|c|c|c|c|}
\hline $\begin{array}{c}\text { Sulfur conc. } \\
(\mathrm{mM})\end{array}$ & \multicolumn{2}{|c|}{$\begin{array}{c}\text { Biomass } \\
(\text { dry weight } \mathrm{g} / \mathrm{L})\end{array}$} & $\begin{array}{c}\text { Lipid content } \\
(\%)\end{array}$ & $\begin{array}{c}\text { Lipids yield } \\
(\mathrm{g} / \mathrm{L})\end{array}$ \\
\hline 0.20 & 1.75 & $\pm 0.14^{\mathrm{a}}$ & $26.98 \pm 1.04^{\mathrm{b}}$ & $0.472 \pm 0.068^{\mathrm{a}}$ \\
\hline 0.40 & 2.32 & $\pm 0.17^{\mathrm{b}}$ & $30.74 \pm 1.34^{\mathrm{c}}$ & $0.713 \pm 0.085^{\mathrm{c}}$ \\
\hline 0.80 & 2.67 & $\pm 0.23^{\mathrm{c}}$ & $34.29 \pm 1.22^{\mathrm{d}}$ & $0.916 \pm 0.078^{\mathrm{d}}$ \\
\hline 1.60 & 3.09 & $\pm 0.32^{\mathrm{d}}$ & $18.43 \pm 0.97^{\mathrm{a}}$ & $0.569 \pm 0.061^{\mathrm{b}}$ \\
\hline
\end{tabular}

Each value represents the mean of three replicates and based on dry weight All values are significant at $(\mathrm{P}<0.5)$.

\section{Effect of nitrogen concentration on SM growth and total lipids}

Nitrogen starvation approaches were as a main factor affecting for accumulation of high lipid content in several microalgae species (Abd El Baky and El Baroty, 2013, 2016). As shown in Table 3, the DW biomass of cultures supplemented with the $2.4 \mathrm{mM}$ nitrogen concentration $(2.982 \mathrm{~g} \mathrm{~mL}-1)$ was higher than that obtained in cultures supplemented with $0.3,0.6$ - and $1.2-\mathrm{mM}$ nitrogen concentration $(1.54,1.89$ and $2.59 \mathrm{~g} \mathrm{~L}$ - 
1). Total lipid contents (TL) and lipid yield (LY) (in parentheses) of SM cells showed an increased trend with increasing $\mathrm{N}$ concentration in a nutrient medium (Table 3). The maximum TL were of $44.65 \%(0.647 \mathrm{~g} / \mathrm{L})$ was obtained in $0.3 \mathrm{mM} \mathrm{N}$ culture, followed by $43.22 \%(0.816 \mathrm{~g} / \mathrm{L})$ in $0.6 \mathrm{mM}(0.793 \mathrm{~g} / \mathrm{L})$ at $1.2 \mathrm{mM} \mathrm{N}$ culture, then $12.45 \%(0.371 \mathrm{~g} / \mathrm{L})$ in $2.4 \mathrm{mM} \mathrm{N}$ culture. In general, the levels of TL and LY in microalgae culture cultivated in $0.3-2.4 \mathrm{mM} \mathrm{N}$-medium significantly $(\mathrm{P}<0.05)$ increase with $\mathrm{N}$ depletion. However, a possible reason for this could be that $\mathrm{N}$ ions are essential for the cell growth and membrane biosynthesis; therefore, the metabolic pathway could be shift from the protein biosynthesis to lipid biosynthesis (Liu et al., 2008; Abd El Baky and El Baroty, 2017).

Table 3. Effect of nitrogen starvation on lipid content and biomass of Spirulina maxima

\begin{tabular}{|c|c|c|c|}
\hline $\begin{array}{c}\text { Nitrogen conc. } \\
(\mathrm{mM})\end{array}$ & $\begin{array}{c}\text { Biomass } \\
(\text { dry weight g/L) }\end{array}$ & $\begin{array}{c}\text { Lipid content } \\
(\%)\end{array}$ & $\begin{array}{c}\text { Lipids yield } \\
(\mathrm{g} / \mathrm{L})\end{array}$ \\
\hline 0.3 & $1.54^{\mathrm{a}}$ & $44.65^{\mathrm{c}}$ & $0.647^{\mathrm{b}}$ \\
\hline 0.6 & $1.89^{\mathrm{b}}$ & $43.22^{\mathrm{c}}$ & $0.816^{\mathrm{d}}$ \\
\hline 1.2 & $2.59^{\mathrm{c}}$ & $30.65^{\mathrm{b}}$ & $0.793^{\mathrm{c}}$ \\
\hline 3.2 & $2.98^{\mathrm{d}}$ & $12.45^{\mathrm{a}}$ & $0.371^{\mathrm{a}}$ \\
\hline
\end{tabular}

Each value represents the mean of three replicates and based on dry weight

All values are significant at $(\mathrm{P}<0.5)$.

Influence of combination of phosphorus, sulfur and nitrogen limitation on the total lipid content and phytosterol contents of SM grown in 300 L photobioreactor (a large scale)

To our knowledge, this is the first report of Egyptian native microalgae, identified as S. maxima cultivated under artificial light and in medium containing three limited concentration of $\mathrm{P}+\mathrm{S}+\mathrm{N}$, in $300 \mathrm{~L}$ closed column photobioreactor ( $\mathrm{PBR}$, at large scale) to produce sufficient biomass to obtain an adequate amount of phytosterols compounds to perform biological assays. Data in Table 4 indicate that the $\mathrm{P}+\mathrm{S}+\mathrm{N}$ limitation in the nutrient growth medium led to an increase in the lipid content. However, total lipids and phytosterols content in SM were 47.33 and $5.54 \%(\mathrm{dw})$, respectively. Therefore, under combination of three $(\mathrm{P}+\mathrm{S}+\mathrm{N})$ elements condition, the $\mathrm{S}$. maxima produced higher amount of phytosterols $(5.54 \%$ of lipid) content than that did in individual element cultures. However, in over all, our results representing that an increase in $\mathrm{P}, \mathrm{S}$ and $\mathrm{N}$ concentrations (over than $0.6,0.6,0.8 \mathrm{mM}$ ) in growth medium resulted in a significant decrease in total sterols yield. However, no report on the effect of nitrogen and phosphorus levels in growth of on sterol accumulation in Spirulina species. Ahmed et al. (2015) reported that no significant change in sterol content could be found at high nitrate or phosphate levels or even at nitrate- and/or phosphate-deprived conditions. On the other hand, interaction effects was found between the light and nutrient concentrations (e.g. phosphorus and/or silicate) on phytosterol content in Scenedesmus and Cyclotella species, that the higher phytosterol content was obtained in cultures grow in low light intensity coupled with low $\mathrm{P}$ content than that made in high P treatment (Piepho, 2010).

Our results corroborate with that reports on a positive interaction between $\mathrm{KNO}_{3}$ concentrations with an increase of biomasses in several Spirulina species (Colla et al., 2007). Generally, Spirulina maxima cells can be manipulated the lipid content which yields a maximum value of about $47.33 \%$ in SM cells grown at phosphorous, sulfur and nitrogen limitation. Also, the results revealed that SM oil containing significant amounts of phytosterols compounds and may help for health promotion and disease prevention. 
Table 4. Effect of nitrogen, phosphorus and sulfur starvation on lipid and phytosterols content and biomass of Spirulina maxima grown in photobioreactor (300 L)

\begin{tabular}{|c|c|c|c|c|}
\hline $\begin{array}{c}\text { Nitrogen, phosphorus } \\
\text { and Sulfur limitation }\end{array}$ & $\begin{array}{c}\text { Biomass } \\
(\text { dry weight g/L) }\end{array}$ & $\begin{array}{c}\text { Lipid content } \\
(\%)\end{array}$ & $\begin{array}{c}\text { lipids yield } \\
(\mathrm{g} / \mathrm{L})\end{array}$ & $\begin{array}{c}\text { Phytosterols } \\
(\%)\end{array}$ \\
\hline $\begin{array}{c}0.6 \mathrm{mM} \mathrm{N}+0.6 \mathrm{mM} \mathrm{P} \\
+0.80 \mathrm{mM} \mathrm{S}\end{array}$ & $2.76 \pm 0.21$ & $47.33 \pm 1.32$ & $1.31 \pm 0.14$ & $5.54 \pm 0.42$ \\
\hline
\end{tabular}

Each value represents the mean of three replicates and based on dry weight

\section{Identification of the phytosterol content in SM grown in photobioreactor}

Phytosterols (PS) of SM grown in 300 L PBR were partially purified from unsaponified extract of SM total lipid and followed purified by recrystallization process. The GC/FID method employed in the present study achieved a good separation of $\beta$-sitosterol, stigmasterol, campesterol and D7-Avena sterol which are among the important phytosterols. $\beta$-Sitosterol, D7-Avena sterol and other phytosterols in SM grown under the combined element limitation (Table 5). The yields ( $\mathrm{mg} / \mathrm{g} \mathrm{dw}$ ) and relative percentage (\%, of the sterol fraction) of the stagmasterol with value of $1.01 \mathrm{mg} / \mathrm{g} \mathrm{dw}$ cells and $6.44 \%$, respectively followed by campesterol $3.16 \mathrm{mg} / \mathrm{g} \mathrm{dw}$ cells and $21.11 \%$, respectively, then b-Sitosterol $(7.72 \mathrm{mg} / \mathrm{g} \mathrm{dw}$ and $49.23 \%)$, D7-Avena sterol $(1.62 \mathrm{mg} / \mathrm{g} \mathrm{dw}$ and $12.12 \%)$ and ergosterol $(0.91 \mathrm{mg} / \mathrm{g} \mathrm{dw}$ and $5.23 \%)$ were also presence a trace phytosterols compounds. Interestingly, a significant variation in quantity of phytosterols content in SM cell was appeared. However, phytoesterol structurally similar to cholesterol and an integral component of algae cell membranes, which playing an important role in the cell stability.

Table 5. Identification of Spirulina maxima phytostreol

\begin{tabular}{|c|c|c|}
\hline Steroids & $\begin{array}{c}\text { Relative content mg/g } \\
\text { (of steroids extract) }\end{array}$ & $\begin{array}{c}\text { Relative } \\
(\% \mathrm{a})\end{array}$ \\
\hline Campesterol & 3.16 & 22.42 \\
\hline Stigmasterol & 1.23 & 7.56 \\
\hline Cholesterol & 1.01 & 6.44 \\
\hline Beta-Sitosterol & 0.91 & 5.23 \\
\hline $\mathrm{D}^{7}$-Avena sterol & 7.2 & 49.23 \\
\hline Ergosterol & 1.62 & 12.12 \\
\hline
\end{tabular}

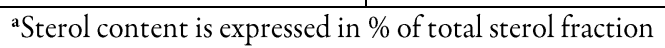

Our results revealed that the b-Sitosterol and $\mathrm{D}^{7}$-Avena sterol was the major phytosterol in SM grown at algae scales in tubler BPR. These results were comprabole with that reported in several previous studies. In early report on phytosterols in Spirulina maxima (blue-green algae,), were by Nadal (1971) who isolated cholesterol and sitosterol as the major phytosteols compounds. Paoletti et al. (1976) found that in three Spirulina species, 24 ethylcholest-5-ene-3b-ol (sitosterol or clionasterol) was the predominant sterol and with a relatively significant amount of cholesterol (3.5-14\%), on the contrary, in green algae. 24-Ethylcholesterol (sitosterol or clionasterol, $79.5 \%$ ) and cholesterol (8.5\%) was identified as a predominated phytosteroids compound in Spirulina maxima (Rzama et al., 1994). However, despite the differences in the relative amounts in sterol composition among blue green algae, Scenedesmus and Chlorella species, and it is often found that two or three particular sterols dominate ((sitosterol and ergosterol) (Paoletti et al., 1976; Rzama, 1994).

The sterol content in several blue green algae was ranged between 0.003 and $0.025 \%$ of dry algal biomass (Razama, 1994). Francavilla et al. (2010) reported that the yields of total sterols were $1.3 \%$ and $0.89 \%$ of $\mathrm{dw}$ in D. tertiolecta and D. salina, respectively, when grow at $0.6 \mathrm{M} \mathrm{NaCl}$ salinity. However, microalgae biotechnology has development due to novel production technologies which allow obtaining high biomass productivities (Chisti, 2007) and major yields of favorite bioactive compounds (Molina Grima et al., 2003). 
On the other hand, the production of phytosterols could be considered as an added-value for Spirulina sp. biomass, which could be cultivated at large scales for production of crude lipids (rich in w3 linolenic acid), proteins, vitamins and also other high added-value byproducts, including phycocynin, carotenoid and antioxidant compounds (Abd El Baky and El Baroty, 2010, 2015) as well as they can reduce atmospheric $\mathrm{CO}_{2}$ ( $\mathrm{CO}_{2}$ bio-mitigation) applying as model of biorefinery (Bai et al., 2011). Hence, production and extraction of high-value phytosterols accompanied the lipid products can potentially offset the high cultivation and production costs and may make Spirullina biomass economic for application is feasible.

\section{Antioxidant activity}

Oxidative stress plays a significant pathological role in induction of many human diseases (Nithiya et al., 2011). Thus, antioxidants are extensively studied for their capacity to protect organism and cell from oxidative damage to biomolecules like DNA, lipids and proteins that play role chronic diseases such as emphysema, cirrhosis, cancer, coronary heart diseases and brain dysfunction (Abd El Baky et al., 2009).

\section{Antioxidant activity of SM steroids by scavenging radical assays}

Antioxidant properties, especially radical scavenging activities, are very important due to the deleterious role of free radicals in food and biological systems. The reduction of $\mathrm{OH}, \mathrm{ABTS}, \mathrm{DPPH}$ and $\mathrm{O}^{-}$is indicative of the capacity of the SM steroids sample to scavenge free radicals, independently of any enzymatic activity. Table 6, illustrates the DPPH, ABTS, OH and superoxide radical scavenging ability of steroids and antioxidant standards (BHT and alpha-tecopherol). Steroids fraction of SM showed excellent DPPH, ABTS, OH and superoxide radicals scavenging activity with dose dependent and $\mathrm{IC}_{50}$ values were $25.73 \pm 1.42,15.24 \pm 1.44$, $21.11 \pm 1.18$ and $19.13 \pm 1.34 \mu \mathrm{g} / \mathrm{ml}$, respectively. Thesevalues for BHA and alpha-tecopherol (in parentheses) were $16.11 \pm 1.33(14.11 \pm 2.22), 11.67 \pm 0.87(11.18 \pm 0.56), 12.44 \pm 0.88(14.21 \pm 0.42)$ and $14.11 \pm 0.91$ $\mu \mathrm{g} / \mathrm{ml}(16.34 \pm 0.54 \mu \mathrm{g} / \mathrm{ml})$, respectively. However, the efficiency of antioxidant capacity was found to be dose depending on manner and on scavenging of radical mechanisms. Based on $\mathrm{IC}_{50}$ values, for scavenging of ABTS, antioxidant efficiency of SM phytosterols was close to that recorded for BHA and alpha-tecopherol standard antioxidants Their result also showed that SP steroids possessed higher scavenging activity in ABTS (act as electron donors) assay than the DPPH (act as hydrogen donating) assay at all different doses used. As shown in Table 5, the four radical systems used for antioxidant evaluation of SM phytosterols showed differences in antioxidant activity could be due to the different mechanisms in radical scavenging. Yu et al. (2002) reported that two or more radical systems are required to assess the radical-scavenging activity of antioxidant. However, scavenging $\left(\mathrm{O}_{2} \bullet-, \mathrm{OH} \bullet, \mathrm{LOO} \bullet\right)$ of free radicals is a potential health interest, that play an important role in the progression of many diseases and pathological disorders, such as atherosclerosis, cataracts and Alzheimer's and Parkinson's diseases, diabetes (type 2) and some types of cancer (Wojcik et al., 2010 and Bachiega et al., 2016). The phytosterols b-sitosterol, stigmasterol, campesterol showed an antioxidant action against oxidation of methyl linoleate in aqueous solution. Its effect due to suppressed the auto-oxidation chain reaction of lipid materials and thereby inhibiting the propagation and promoting termination reactions (Yoshida and Nika, 2003). Vivacons and Moreno (2005) also suggest that phytosterols (b-sitosterol) are responsible for the preventive effects on the development of diseases due to its antioxidant effect. On the other hand, Gordon et al. (1983) reported that the phytosterols, particularly 5-avenasterol act as antioxidants and as antipolymerization agents in frying oils. 
Table 6. In vitro superoxide, DPPH and OH radical scavenging activity of Spirulina maxima phytosterols, BHA and $\alpha$-tocopherol

\begin{tabular}{|c|c|c|c|c|}
\hline \multirow{2}{*}{ Assay } & \multicolumn{3}{|c|}{ IC $_{50}\left(\mu \mathrm{g} \mathrm{ml}{ }^{-1}\right)$} & $\begin{array}{c}\text { LSD } \\
(\mathrm{P}< \\
\end{array}$ \\
\cline { 2 - 5 } & BHA & $\beta$-Tocopherol & SM phytosterol & $0.05)$ \\
\hline DPPH. scavenging radical) & $16.11 \pm 1.33$ & $14.11 \pm 2.22$ & $25.73 \pm 1.42$ & 1.86 \\
\hline ABTS scavenging radical & $11.67 \pm 0.87$ & $11.18 \pm 0.56$ & $15.24 \pm 1.44$ & 1.52 \\
\hline OH. scavenging radical & $12.44 \pm 0.88$ & $14.21 \pm 0.42$ & $21.11 \pm 1.18$ & 1.78 \\
\hline $\begin{array}{c}\text { Superoxide scavenging } \\
\text { radical }\end{array}$ & $14.11 \pm 0.91$ & $16.34 \pm 0.54$ & $19.13 \pm 1.34$ & 1.95 \\
\hline
\end{tabular}

Table 7. Antiproliferation activity of Spirulina maxima agtensis steroid against three model's human cancer cell lines and Paclitaxel standard anticancer drug

\begin{tabular}{|c|c|c|}
\hline \multirow{2}{*}{ aHuman cancer cell lines } & \multicolumn{2}{|c|}{ IC $_{50} \mathrm{\mu g} / \mathrm{ml}$} \\
\cline { 2 - 3 } & SM phytosterols & ${ }^{\mathrm{b}}$ Paclitaxel \\
\hline MCF-7 & 5.49 & 0.45 \\
\hline HepG2) & 11.42 & 0.52 \\
\hline HCT-116 & 6.68 & 0.35 \\
\hline
\end{tabular}

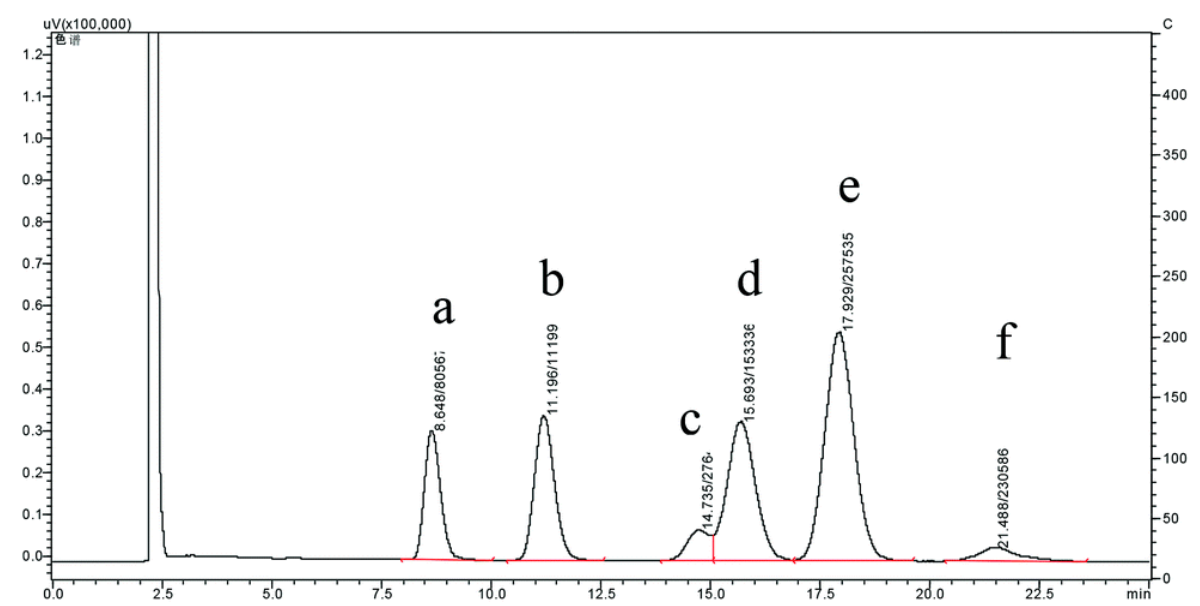

Figure 1. GC/FID Identification of Spirulina maxima phytosterol

\section{In vitro antiproliferative activity}

The phytosterols of SM cells grown at large scale in photobioreactor (300 L, P+S+N) were tested in vitro for its potential human cancer cell growth inhibitory effect on three (MCF-7, Hep G2 and HCT-116) cancer cell line using MTT assay, that assay is widely used to quantify cell viability and proliferation (Table 7). The incubation of three cell lines with increasing concentration of SM steroids caused a gradual inhibition of cell growth as concluded from its low IC S0 $_{0}$ value of $5.49,11.42$ and $6.68 \mu \mathrm{g} / \mathrm{ml}$, respectively. The IC s0 $_{0}$ value of Paclitaxel anticancer drug against tested cell lines was $0.45,0.52$ and $0.35 \mu \mathrm{g} / \mathrm{ml}$, respectively. The anticancer action of SM phytosterols (containing ß-sitosterol, campesterol and stigmasterol) may be compatible with the potential inhibitory effect of phytosterols compounds against breast, colon and prostate human cancer cell lines (Cilla et al., 2015). Baskar et al. (2010) and Jayaprakasha et al. (2010) found that ß-sitosterol (from sour 
orange) induced a significant dose-dependent growth inhibition of colon 320 cells and HT-29 cells by inducing apoptosis action throughout scavenging of reactive oxygen species. Also, B-sitosterol significantly inhibited the growth and induced apoptosis in SGC-7901 human stomach cancer cells (Zhao et al., 2009). In addition, phytosterols isolated from evening primrose oil and its main components ß-sitosterol and campesterol showed a reduction in cell proliferation, apoptosis induction and arrest the cell cycle of colon cancer HT-29 (Montserrat-de la Paz et al., 2015). Stigmasterol isolated from Navicula incerta marine algae induced apoptosis in human hepatocarcinoma Hep G2 cells (Kim et al., 2014). Moreover, it has been reported that the antioxidant activity of phytosterols may explain, at least in part, their anticancer effect in mice (Liu et al., 2010), and can be attributed to protect the cells from oxidative stress damage by inhibiting mitochondrial ROS formation (Llaverias et al., 2013). In general, the phytosterols may be inhibiting the cancer cell growth due to its function in proliferation, signal transduction and modulating the activity of membrane-bound enzymes of cancer cells, slowing of cell cycle progression and the inhibition of tumor metastasis (Bradford and Awad, 2007; Woyengo et al., 2009).

\section{Conclusions}

Cultivation of SM under N, P and S nutrient insufficient condition, the total lipid and phytosterol contents were enhanced compared with that at high concentrations. At large scale in 300L photobireactor, culture of SM in combination of N, P and S limitation media, the highest total lipid and phytosterol was achieved comparable with that in individual cultures. The phytosterols of partially purified phytosterol-rich fraction isolated from unsaponified extract of total lipid of SM cells followed by recrastilization, showed antioxidant and in vitro inhibitory effect on the growth of three human (MCF-7, HepG2 and HCT-116) cancer cell line. Thus, these results are quite related to the phytosterol (PS) contents of the Spirulina maxima fractions and might provide a promising role in future medicines as anti-oxidant and anti-cancer.

\section{Acknowledgements}

This research received no specific grant from any funding agency in the public, commercial, or not-forprofit sectors.

\section{Conflict of Interests}

The authors declare that there are no conflicts of interest related to this article.

\section{References}

Abd El Baky HH, El Baz FK, El-Baroty GS (2006). Over-production of lipid rich in linolenic acid by blue green alga Spirulina maxima and its inhibitory effect on carcinoma cells. Advances in Food Sciences 28(4):206-213.

El Baky HH, El Baz FK, El-Baroty GS (2009). Phenolics from Spirulina maxima: over-production and in vitro protective effect of its phenolics on CCl4 induced hepatotoxicity. Journal of Medicinal Plant Research 3(1):24-30.

Abd El Baky HH, El Baroty GS (2012). Characterization and bioactivity of phycocyanin isolated from Spirulina maxima grown under salt stress. Food \& Function 3(4):381-388.

Abd El Baky HH, El-Baroty GS (2013). The potential use of microalgal carotenoids as dietary supplements and natural preservative ingredients. Journal of Aquatic Food Product Technology 22(4):392-406. 
Abd El Baky HH, El Baz FK, El Baroty GS, Asker MS, Ibrahim EA (2014). Phospholipids of some marine macroalgae: Identification, antivirus, anticancer and antimicrobial bioactivities. Der Pharma Chemica 6(5):370-382.

Abd El Baky HH, El Baroty GS (2016). Optimization of growth conditions for purification and production of Lasparaginase by Spirulina maxima. Evidence-Based Complementary and Alternative Medicine.

Abd El Baky HH, El Baroty GSA, Ibrahem EA (2016). Functional characters evaluation of biscuits sublimated with pure phycocyanin isolated from Spirulina and Spirulina biomass. Nutricion Hospitalaria 32(1):231-241.

Ahmed F, Zhou W, Schenk PM (2015). Pavlova lutheri is a high-level producer of phytosterols. Algal Research 10:210217.

Andrade LM, Andrade CJ, Dias M, Nascimento CA, Mendes MA (2018). Chlorella and Spirulina microalgae as sources of functional foods, nutraceuticals, and food supplements; an overview. MOJ Food Processing \& Technology 6(1):45-58.

Abdul QA, Choi RJ, Jung HA, Choi JS (2016). Health benefit of fucosterol from marine algae: a review. Journal of the Science of Food and Agriculture 96(6):1856-1866.

Bachiega P, Salgado JM, de Carvalho JE, Ruiz ALT, Schwarz K, Tezotto T, Morzelle MC (2016). Antioxidant and antiproliferative activities in different maturation stages of broccoli (Brassica oleracea Italica) biofortified with selenium. Food Chemistry 190:771-776.

Bai M, Cheng C, Wan H, Lin Y (2011). Microalgal pigments potential as byproducts in lipid production. Journal of the Taiwan Institute of Chemical Engineers 42(5):783-786.

Baskar A, Ignacimuthu S, Paulraj GM, Al Numair KS (2010). Chemopreventive potential of $\beta$-Sitosterol in experimental colon cancer model -an in vitro and in vivo study. BMC Complementary and Alternative Medicine 10(1):24.

Bligh EG, Dyer WJ (1959). A rapid method of total extraction and purification. Canadian Journal of Biochemistry and Physiology 37(8):911-917.

Borowitzka MA (2013). High-value products from microalgae-their development and commercialization. Journal of Applied Phycology 25(3):743-756.

Bradford PG, Awad AB (2007). Review: phytosterols as anticancer compounds. Molecular Nutrition and Food Research 51(2):161-170

Celekli A, Yavuzatmaca M, Bozkurt H (2009). Modeling of biomass production by Spirulina platensis as function of phosphate concentrations and $\mathrm{pH}$ regimes. Bioresource Technology 100(14):3625-3629.

Chuanphongpanich S, Nipon T, Duang Buddhasukh D, Pirakitikulr P, Phanichphant S (2006). Stanol synthesis from palm oil distillate. Chiang Mai Journal of Sciences 33(1):109-116.

Chiu SY, Kao CY, Tsai MT, Ong SC, Chen CH, Lin CS (2009). Lipid accumulation and $\mathrm{CO}_{2}$ utilization of Nannochloropsis oculata in response to $\mathrm{CO}_{2}$ aeration. Bioresource Technology 100(2):833-838.

Cilla A, Attanzio A, Barberá R, Tesoriere L, Livrea MA (2015). Anti-proliferative effect of main dietary phytosterols and B-cryptoxanthin alone or combined in human colon cancer Caco-2 cells through cytosolic $\mathrm{Ca}^{+2}$ and oxidative stressinduced apoptosis. Journal of Functional Foods 12:282-293.

Colla LM, Reinehr CO, Reichert C, Costa JAV (2007). Production of biomass and nutraceutical compounds by Spirulina platensis under different temperature and nitrogen regimes. Bioresource and Technology 98(7):489-1493.

El Baroty GS, El Baz FK, Abd-Elmoein I, Abd El-Baky HH, Ail MM, Ibrahim EA (2011). Evaluation of glycolipids of some Egyptian marine algae as a source of bioactive substances. Electronic Journal of Environmental, Agricultural and Food Chemistry 10(4):2114-21218.

Fernandes P, Cabral JMS (2007). Phytosterols: applications and recovery. Bioresources and Technology 98:2335-2350.

Halliwell B, Gutteridge JMC, Aruoma OI (1987). The deoxyribose method: A simple 'test tube' assay for determination of rates constants for reactions of hydroxyl radical. Analytical Biochemistry 165(1):215-224.

Gordon MH, Magos P (1983). The effect of sterols on the oxidation of edible oils. Food Chemistry 10(2):141-147.

Gordillo FJL, Goutx M, Figueroa FL, Niell FX (1998). Effects of light intensity, $\mathrm{CO}_{2}$ and nitrogen supply on lipid class composition of Dunaliella viridis. Journal of Applied Phycology 10(2):135-144.

Jayaprakasha GK, Jadegoud Y, Gowda GA, Patil BS (2010). Bioactive compounds from sour orange inhibit colon cancer cell proliferation and induce cell cycle arrest. Journal of Agricultural and Food Chemistry 58(1):180-186.

Kim Y, Li X, Kang K, Ryu B, Kim S (2014). Stigmasterol isolated from marine microalgae Navicula incerta induces apoptosis in human hepatoma HepG2 cells. BMB Reports 47(8):433-438.

Koh EJ, Kim KJ, Choi J, Kang DH, Lee BY (2018). Spirulina maxima extract prevents cell death through BDNF activation against amyloid beta 1-42 (Aß induced neurotoxicity in PC12 cells. Neuroscience Letters 673:33-38. 
Liu ZY, Wang GC, Zhou BC (2008). Effect of iron on growth and lipid accumulation in Chlorella vulgaris. Bioresource Technology 99(11):4717-4722.

Liu M, Sakamaki T, Casimiro MC, Willmarth NE, Quong AA, Ju X (2010). The canonical NF-kappaB pathway governs mammary tumorigenesis in transgenic mice and tumor stem cell expansion. Cancer Research 70(24):1046410473.

Llaverias G, Escola-Gil JC, Lerma E, Julve J, Pons M, Ros E, ... Blanco-Vaca F (2013). Phytosterols inhibit the tumor growth and lipoprotein oxidizability induced by a high-fat diet in mice with inherited breast cancer. Journal of Nutritional Biochemistry 24(1):39-48.

Luo X, Su P, Zhang W (2015). Advances in microalgae-derived phytosterols for functional food and pharmaceutical applications. Marine Drugs 13(7):4231-4254.

Martin-Creuzburg D, Von Elert E (2009). Ecological significance of sterols in aquatic food webs. In: Arts MT, Brett MT, Kainz MJ, eds. Lipids in Aquatic Ecosystems. Springer, New York pp 43-64.

McCord JM, Fridovich I (1969). Superoxide dismutase: an enzymic function for erythrocuprein (hemocuprein). Journal of Biological Chemistry 244(22):6049-6055.

Molina Grima E, Belarbi EH, Acien Fernandez FG, Robles Medina A, Chisti Y (2003). Recovery of microalgal biomass and metabolites: process options and economics. Biotechnologies Advances 20(7-8):491-515.

Montserrat-de la Paz S, Fernandez-Arche MA, Bermudez B, Garcia-Gimenez M (2015). The sterols isolated from evening primrose oil inhibit human colon adenocarcinoma cell proliferation and induce cell cycle arrest through upregulation of LXR. Journal of Functional Foods 15:64-69.

Nadal NGM (1971). Sterols of Spirulina maxima. Phytochemistry 10:2537-2538.

Paoletti C, Pushparaj B, Florenzano G, Capella P, Lercker G (1976). Unsaponifiable matter of green and blue-green algal lipids as a factor of biochemical differentiation of their biomasses: I. Total unsaponifiable and hydrocarbon fraction. Lipids 11(4):266-271.

Piepho M, Martin-Creuzburg DM, Wacker A (2010). Simultaneous effects of light intensity and phosphorus supply on the sterol content of phytoplankton. PLoS ONE 5(12):e15828.

Rao AR, Dayananda C, Sarada R, Shamala TR, Ravishankar GA (2007). Effect of salinity on growth of green alga Botryococcus braunii and its constituents. Bioresource Technology 98(3):560-564.

Re R, Pellegrini N, Proteggente A, Pannala A, Yang M, Rice-Evans C (1999). Antioxidant activity applying an improved ABTS radical cation decolorization assay. Free Radical Biology and Medicine 26(9-10):1231-1237.

Rzamaa A, Dufourc EJ, Arregub B (1994). Sterols from green and blue-green algae grwn on reused waste water. Phytochemistry 37(60):1625-1628.

Shanthi G, Premalatha M, Anantharaman N (2018). Effects of L-amino acids as organic nitrogen source on the growth rate, biochemical composition and polyphenol content of Spirulina platensis. Algal Research 35:471-478.

Srigley CT, Haile EA (2015). Quantification of plant sterols/stanols in foods and dietary supplements containing added phytosterols. Journal of Food Composition and Analysis 40: 163-176.

Tang D, Han W, Li P, Miao X, Zhong J (2011). $\mathrm{CO}_{2}$ biofixation and fatty acid composition of Scenedesmus obliquus and Chlorella pyrenoidosa in response to different $\mathrm{CO}_{2}$ levels. Bioresource Technology 102(3):3071-3076.

Vivacons M, Moreno JJ (2005). Beta-sitosterol modulates antioxidant enzyme response in RAW 264.7 macrophages. Free Radical Biology and Medicine 39(1):91-97.

Wojcik M, Burzynska-Pedziwiatr I, Wozniak LA (2010). A review of natural and synthetic antioxidants important for health and longetivity. Current Medicinal Chemistry 17(28):3262-3288.

Woyengo TA, Ramprasath VR, Jones PJ (2009). Anticancer effects of phytosterols. European Journal of Clinical Nutrition 63(7):813-820.

Yoshida Y, Niki E (2003). Antioxidant effects of phytosterol and its components. Journal of Nutritional Science and Vitaminology 49(4):277-280.

Yu L, Haley S, Perret J, Harris M, Wilson J, Qian M (2002). Free radical scavenging activity properties of wheat extracts. Journal of Agricultural and Food Chemistry 50(6):1619-1624.

Zhao Y, Chang SK, Qu G, Li T, Cui H (2009). B-Sitosterol inhibits cell growth and induces apoptosis in SGC-7901 human stomach cancer cells. Journal of Agricultural and Food Chemistry 57(12):5211-5218.

Winkler-Moser J (2018). Gas chromatographic analysis of plant sterols. The AOCS Lipid Library. https://doi.org/10.21748/lipidlibrary.40384 
Zarrouk C (1966). Contribution a letuded unecyanobacterie: influence de divers facteurs physiques et chimiquessur la croissance et la photosynthese de Spirulina maxima (Setchell et Gardner) Geitler[Ph.D. thesis], University of Paris, Paris, France.

OPEN ACCESS

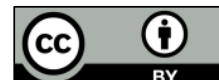

The journal offers free, immediate, and unrestricted access to peer-reviewed research and scholarly work. Users are allowed to read, download, copy, distribute, print, search, or link to the full texts of the articles, or use them for any other lawful purpose, without asking prior permission from the publisher or the author.

License - Articles published in Notulae Botanicae Horti Agrobotanici Cluj-Napoca are Open-Access, distributed under the terms and conditions of the Creative Commons Attribution (CC BY 4.0) License. (C) Articles by the authors; UASVM, Cluj-Napoca, Romania. The journal allows the author(s) to hold the copyright/to retain publishing rights without restriction. 